\title{
LIFE HISTORY STRATEGIES OF THE MONTANE VOLE, MICROTUS MONTANUS
}

\author{
Frederick J. Jannett, Jr. \\ Department of Biology \\ The Science Museum of Minnesota \\ St. Paul
}

\section{Objectives}

Emphasis in microtine rodent biology has historically been placed on population regulation and the population cycle. Until recently, little attention has been directed to behavior and sociality in microtine rodents, but work on the sociobiology of the montane vole (Jannett, 1978, 1980, 1981, 1982, 1984) is serving to integrate various aspects of the biology of this species so that its life history characteristics can be interpreted in an evolutionary framework. Work undertaken in 1986 continues previously initiated surveys of various topics, such as synchrony of population events in different populations, survivorship, scent gland development, patterns of cranial and dental variation, population trends in a sympatric species of vole ( . . longicaudus), and reproduction in a primary predator, the shorttail weasel Mustela erminea).

\section{Methods}

Microtus montanus were trapped in 8 populations in late May including 2 in South Park, 3 near Moran, and 2 near Togwottee Pass where snow meltoff was early. The three sites near Moran had been sampled in previous Mays. In October, 18 samples were made in the Moran area and in the Grassy Lake district. These efforts included 3 gridded areas and 15 transects, many of wich replicated samples in 1971-1977 and 19821986. At the suggestion of Ken Diem, the two new sample sites were north of GTNP along the Grassy Lake Road. Most samples were run for only two days so that impact on the respective populations would be minimized. Eyes were removed for age determination upon lens weight (Gourley and Jannett, 1975). As in previous years, three populations of Microtus longicaudus were sampled in October. However, because there was no snow cover in late October, no effort was made to secure shorttail weasels.

Results

Microtus montanus: Voles were uncommon in May at all sites and there were insufficient numbers outside of the context of the longitudinal multiyear series to make any generality about survivorship. However, 
voles in populations in South Park obviously started breeding earliest and at Togwottee Pass last, as evidenced by pregnancies and weight distributions of pups and subadults.

In general, populations around Moran increased between October, 1986, and October, 1987. Of the 16 sites previously trapped, 7 are open fields which usually support relatively large numbers of voles. The sample decreased in one of these and increased by as much as a factor of 7.4 in the other six. Of the nine sites which may be considered as dispersal sinks, there was no vole in one, and small numbers in each of the others.

The one previously established trap site north of the Research Center and the two new sites near Grassy Lake were amongst the four sites where the trap effort was most successful.

One or more parous females were found in each of 16 sites. In each of nine of these sites, one or more of these parous females were still lactating and/or pregnant. Most striking was the presence of firstpregnancy females despite the absence of measurable precipitation for about 2 months.

One or more males with scrotal testes were found at each of only eight sites. Each of 7 of these sites and 2 others yielded adult female(s). There was no obvious correlation between the percentage of females still lactating and/or pregnant and the operational sex ratio, as had been found in 1983 and 1984. Figure 1 depicts the relation between percentage of parous and nulliparous-pregnant females still reproductively active and the percentage of males with scrotal testes among these adults.

Microtus longicaudus: Numbers of voles at three sites remained similar to those in previous years.

Mustela erminea: One female ermine was secured incidental to vole work.

\section{Conclusions}

Krebs and Myers (1974) concluded that there is a general pattern in microtine demography in which breeding ceases earlier in years of very high density. Making short-term samples of $\mathrm{M}$. montanus in proximate populations within a few weeks in October, 1984 demonstrated that variability in the length of the "breeding season" can occur in the same year at high densities and that it is correlated with the operational sex ratio. In 1986, sampling a number of populations showed the "breeding season" to be of variable duration even at very low densities.

By adding two more northerly sites in 1987, where populations were considerably higher than in most previously established sites, a greater 


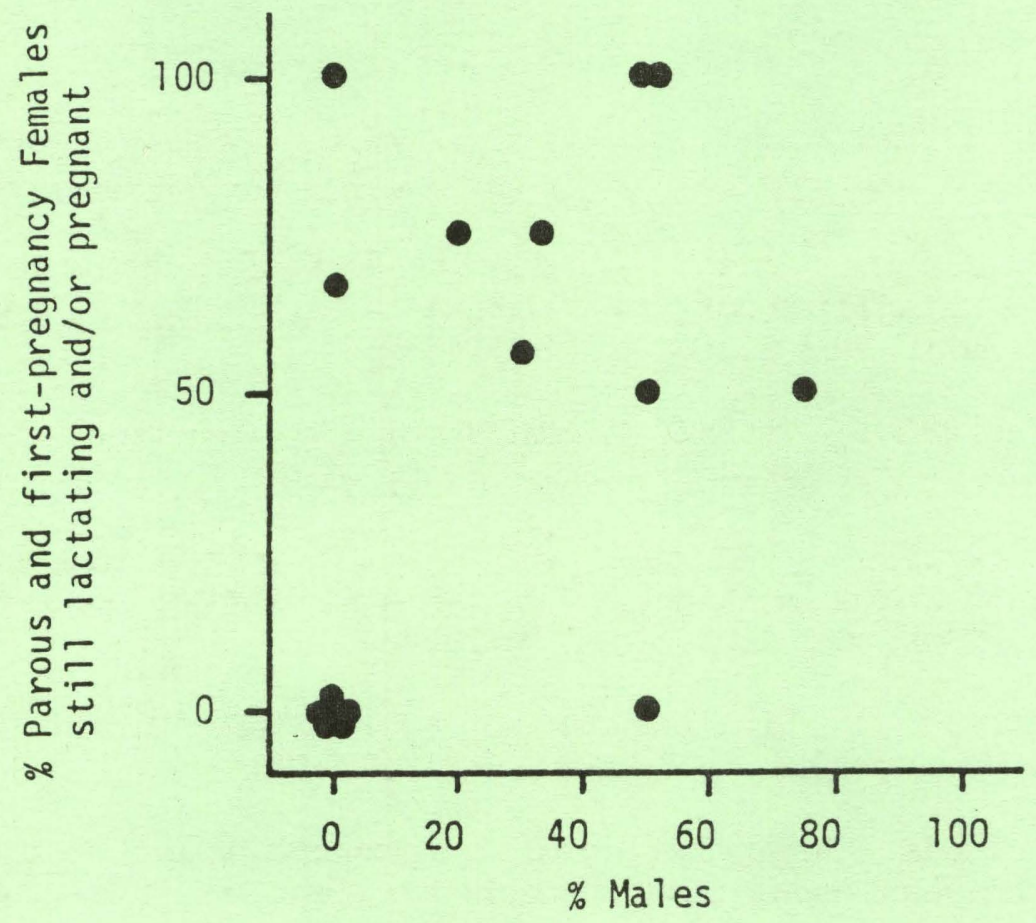

Figure 1. Percentages of adult males with scrotal testes among males witi scrotal testes, parous females, and pregnant nulliparous females versus percentages of adult females reproductively active in October, based on initial gross examinations of specimens. ( $n=57$ adult females) 
range of densities was covered within one year than had been heretofore found. This region may have populations which eventually are shown to be in different demographic phases than those more southerly populations. However, population processes and indicators thereof, e. g.. relatively few adult males and early cessation of breeding, were the most pronounced in the Grassy Lake populations and these patterns have been typical of more dense vole populations (Krebs and Myers, 1974; Jannett, 1981). The populations may be out of synchrony but illustrate the same underlying mechanisms.

\section{Literature Cited}

Gourley, R. S. and F. J. Jannett, Jr. 1975. Pine and montane vole age estimates from eye lens weights. J. Wildl. Manage., 39:550-556.

Jannett, F. J., Jr. 1978. The density-dependent formation of extended maternal families of the montane vole, Microtus montanus nanus. Behav. Ecol. and Sociobiol., 3:245-263.

1980. Social dynamics of the montane vole, Microtus montanus, as a paradigm. Biologist, 62:3-19.

- 1981. Sex ratios in high-density populations of the montane vole, Microtus montanus, and the behavior of territorial males. Behav. Ecol. and Sociobiol., 8:297-307.

- 1982. Nesting patterns of adult voles, Microtus montanus, in field populations. J. Mammal., 63:495-498.

- 1984a. Reproduction of the montane vole, Microtus montanus, in subnivean populations. Carnegie Mus. Nat. Hist., Special Publ. $10: 215-224$.

1984b. Sex ratios and late fall breeding in the montane vole, Microtus montanus. Amer. Zool., 24:3A. (Abstract)

Krebs, C. J. and J. H. Myers. 1974. Population cycles in small mammals. Adv. Ecol. Res., 8:267-399.

\section{Acknowledgements}

I thank the National Park Service for permission to work in Grand Teton National Park, the University of Wyoming-National Park Service Research Center for its hospitality, and Dr. Ken Diem for the loan of Research Center traps and for suggesting the more northerly sites. This work was supported by the Science Museum of Minnesota. 